\title{
A Digitális Kreybig Talajinformációs Rendszer alkalmazása térségi szintű földhasználati kérdések megoldásában
}

\author{
SZABÓ JÓZSEF, PÁSZTOR LÁSZLÓ, BAKACSI ZSÓFIA, LÁSZLÓ PÉTER \\ és LABORCZI ANNAMÁRIA
}

MTA Talajtani és Agrokémiai Kutatóintézet (MTA TAKI), Budapest

\section{Bevezetés}

A talaj sokrétü funkciói (BLUM, 1993; VÁRALLYAY, 1997) közül a legutóbbi időkig a biomassza-termelés kapcsán szóba jövők voltak a legfontosabbak, napjainkban azonban egyre inkább felértékelödnek a környezet minőségével kapcsolatosak (VÁRALLYAY, 2002a); a társadalom egyre inkább igényt tart és a fenntartható fejlődés is a talaj multifunkcionalitására épít (VÁRALLYAY, 2001, 2002b). Ebből következően a talajokra vonatkozó információk már rég nem csupán az agrárium részére alapvetőek; a környezetvédelem számos területe, a földértékelés, a szaktanácsadás, a vízgazdálkodás és - a jelen munkánkat indukáló - területi tervezés számára is elengedhetetlenek. A talajokra vonatkozó információ-igények kielégítésére született talajtérképek, majd a szisztematikus talajfelvételezéseken alapuló talajtérképezések során a felvételezés meghatározó szempontjai általában mezőgazdasági jellegüek voltak (HUBRECHTS et al., 1998). Következésképpen az általuk szolgáltatott információk nem mindig fedik az aktuálisan vizsgált funkciók kapcsán megkívántakat. Ugyanakkor a hagyományos talajfelvételezés és -térképezés idő- és költségigényes volta miatt egyre nagyobb szerepet kap a rendelkezésre álló információk mind alaposabb kiaknázása. Új adatfelvételezés híján ezen ellentmondás feloldására az elméleti talajtantól várhatók megfelelő megoldások, melyek alapanyagát a talajtani adatbázisok és térbeli talajinformációs rendszerek adják. Jelentős szerepet kapnak az egyes környezeti paraméterekre vonatkozó térképi alapú, digitális ismeretek, melyek egyrészt jelentősen kisebb költséggel szerezhetők be, másrészt a digitális talajtérképezés eszközeivel felhasználhatók a talajok bizonyos tulajdonságainak becslő meghatározására (ld. pl. DOBOS et al., 2002; MCKENZIE \& GALLANT, 2005). Megfelelő pedotranszfer függvények bevezetésével és kalibrációjával szintén jelentős előretörés várható a rendelkezésre álló talajtani információk sokrétü felhasználhatóságában (ld. pl. WÖSTEN et al., 1998; FODOR \& RAJKAI, 2005).

Napjainkban a területhasználati célok nagyon sokfélék: biomassza termelése élelmiszer, takarmány, nyersanyag vagy energia célra; népesség-foglalkoztatás;

Postai cím: PÁSZTOR LÁSZLÓ, MTA Talajtani és Agrokémiai Kutatóintézet, GIS Labor, 1022 Budapest, Herman Ottó út 15.E-mail: pasztor@rissac.hu 
nyersanyag-kitermelés; építési terület; üdülés, sport, rekreáció; esztétikus táj; biodiverzitás megörzése (VÁRALLYAY \& LÁNG, 2000). A birtokrendezés, a települési, megyei, országos rendezési tervek, illetve az ezekben megfogalmazódó, a földhasználatot érintő konverziókra való ajánlások megtétele nem nélkülözheti a térségi földhasználat többszempontú értékelését. Az önmagukban is igen komplex földhasználati célok környezeti (és föképp társadalmi) modellezése egyenként sem könnyü feladat, az összehasonlíthatóságukhoz elengedhetetlen együttes elemzésük azonban komoly kihívást jelent több szempontból is. Nem triviális az egyes földhasználatok alkalmasságának meghatározása, számszerüsítése pedig föképp nem. Ez utóbbi pedig elengedhetetlen a potenciális („versengő”) területhasználatok öszszehasonlításához, az optimálisra vonatkozó ajánlások megtételéhez. A területrendezés, vidékfejlesztés pedig válaszokat vár stratégiájának kialakításához, terveinek elkészítéséhez.

\section{Hazai elözmények}

A környezeti (nem társadalmi) meghatározottságú terület- és földhasználat értékelésére a közelmúltban is számos kezdeményezés történt Magyarországon. Ez egyrészt a talaj minőségére alapozott egyszerü termőhely kategorizálásnál jóval szélesebb problémakört jelent (MAGYARI, 2005), másrészt a talajokra vonatkozó területi információk, illetve azok célspecifikus interpretációja nélkül nem kivitelezhetö. A földhasználat, -értékelés témában több összefoglaló mủ jelent meg az elmúlt évek során is (LÓCZY, 2002; BIRKÁs, 2006; DÖMSÖDI, 2006), mely kiadványok nagyon részletesen tárgyalják e komplex terület legapróbb részleteit is, a területi tervezés számára napi szinten alkalmazható általános megoldásokkal azonban nemigen szolgálnak. Vannak természetesen az operatív alkalmazások téren is jelentős elörelépések. A D-e-Meter intelligens környezeti földminősítő rendszer egy tudományos alapokon nyugvó földminőségi paraméter meghatározása révén az eltérő földhasználati típusok gazdasági és ökológiai értékelésére alkalmas (GAÁL et al., 2003). A D-e-Meter projekt folytatásának meghatározó lépése az erdő- és gyeptalajok talajértékszám-kalkulációs tervének kidolgozása. Mindkét mutató a föld termékenységén alapul, figyelembe véve a szakmai hagyományokat az erdők és a gyepek esetén is. A rendszer egyik fö végterméke a lehetséges földhasználati alternatívák értékelö összehasonlítása lesz. TAMÁs (2006) szintén a farmszintü, nagy méretarányú agrár- és környezetvédelmi célú földhasználati konfliktusok kezelésére vállalkozik térbeli optimalizációs eljárásokra támaszkodva. MAGDA és munkatársai (2006) az Észak-Magyarországi Régióban indítottak módszertani fejlesztést az agráralkalmassági és földhasználati viszonyok elemzésére, melynek fö célkitüzése strukturált ismeret szolgáltatása a gazdálkodóknak, szaktanácsadóknak, térségfejlesztőknek és tervezőknek a bevezetendő, pályázható, alkalmazható agrárkörnyezetgazdálkodási, vidékfejlesztési EU-s programok kidolgozásához ajánlati modellek kidolgozása révén. CSETE és LÁNG (2004) a szántóföldi agroökoszisztémák értékelésére egy pontrendszerben kifejezett potenciálon alapuló módszert dolgozott ki. 
A magyarországi földhasználat értékelésének áttekintő, könnyen interpretálható és a területi tervezés számára alkalmazható módszertanának kidolgozását ÁNGYÁN és munkatársai (1999) kezdeményezték. Országos szinten az ún. agráralkalmasságkörnyezetérzékenység egydimenziós skála mentén tettek kísérletet egy egységes földminősítési rendszer, illetve az erre alapozott földhasználati zónarendszer kidolgozására. A zonációs alapvizsgálat a fellelhető térképi alapú adatbázisok komplex térinformatikai elemzésével kereste a választ arra, hogy mely tényezők határozzák meg egy terület mezőgazdasági termelésre való alkalmasságát és ez hogyan kapcsolódik ugyanezen területek környezeti érzékenységéhez. Ezen megközelítés legfőbb jelentősége annak módszertani érvényesítése, hogy egy terület értékességét nemcsak megszokott, mezögazdálkodásra vonatkozó paraméterek (mint pl. a szántóföldi növénytermesztési alkalmasság) határozzák meg, hanem a környezeti, természeti értékek jelenléte is (ami a talaj bővülő funkcióinak terén bekövetkezett paradigmaváltással analógnak tekinthető szemléletváltást jelez). Az agráralkalmasság és környezeti érzékenység mellett egy harmadik földhasználati cél, mint pl. az erdőgazdálkodás megjelenése egyrészt a problémakör finomításaként tekinthető, másrészt szükségessé tette a korábban alkalmazott zónációs metodika módosítását (MAGYARI, 2005). Ennek során az egyes tényezőket függetlenül elemezték és az ennek eredményeként kialakuló, területegységekre vonatkozó kombinációkat ökotípusoknak nevezték. Az egyes ökotípusok legalább egy tényező tekintetében eltérnek egymástól. Az ökotípusok jól használhatók a jelenlegi térszerkezet elemzésére és a müvelési ág változásokra vonatkozó javaslatok megfogalmazására, viszont nehezen kezelhetők, amennyiben számosságuk túl nagy. Ez azt jelenti, hogy az egyes tényezőket nem érdemes túl finom kategóriarendszerbe sorolni, hanem viszonylag egyszerủ, egyparaméteres osztályozásukra érdemes törekedni. PODMANICKY és munkatársai (2006) az Állami Erdészeti Szolgálat megbízásából kidolgozták a „kiváló termőhelyi adottságú szántóterületek”, az „erdőtelepítésre, fásításra alkalmas területek”, valamint az „országos erdőgazdálkodási térségek” lehatárolásának módszertanát és elvégezték ezek alapján a megfelelő ökotípusos földhasználati lehatárolást az Országos Területrendezési Terv számára. A módszertan céljához igazodóan országos léptékủ térképi alapú információkat vett figyelembe, többek között a talajok vonatkozásában is. A következő lépés a módszertan az országossal konzisztens megyei és település szintü lépcsőinek kidolgozása volt. Jelen tanulmány Magyarország ökotípusos földhasználati vizsgálatának megyei szinten történő talajtani adatigényének kielégítését tekinti át.

\section{Anyag és módszer}

Az Országos Területrendezési Terv számára elkészült módszertan, céljához igazodóan, országos léptékủ térképi alapú információkat vett figyelembe, természetesen a talajok vonatkozásában is. Hazánk agroökológiai potenciáljának felmérése 1978-1980 között történt meg (LÁNG et al., 1983). Ezen program keretében került sor a talajkészletek mennyiségi és minőségi számbavételére, amelynek eredménye az Agrotopográfiai térképsorozat (VÁRALLYAY et al., 1979, 1980). A talajokról 
rendelkezésre álló információk térképi alapú szintézise után a talajtulajdonságok térbeni eloszlásának és időbeni változásainak szisztematikus regisztrációja, azaz a talajmonitoring került elötérbe. Hazánkban 1992 óta üzemel a Talajvédelmi Információs és Monitoring Rendszer, melynek koncepcióját és rendszertervét az MTA TAKI irányításával szakértői bizottság dolgozta ki 1991-ben (VÁRALLYAY, 1995).

Az országos szinten a szántóföldi alkalmasság értékelése során használt mindhárom értékelési tényező az AGROTOPO térbeli talajinformációs rendszer (SZABÓ \& PÁSZTOR, 1994) egy-egy paramétere volt: a talajok fizikai félesége, a talajok kémhatása és mészállapota, illetve a talajok vízgazdálkodása. Az erdőtelepítési alkalmasság meghatározása során az erdőgazdálkodásra való alkalmasság négy értékelési tényezője közül három szintén az AGROTOPO egy-egy paramétere volt: a talajok genetikai típusa, a talajok kémhatása és mészállapota, illetve a talajok vízgazdálkodása. Az erdő védelmi funkciója iránti igény négy tényezője közül egy szintén ebből a forrásból származik: a talajok fizikai félesége. A környezeti érzékenység meghatározásánál az egyik tényező az ún. talajérzékenység, amit a tanulmány a potenciális erózió mértékével fejezett ki (amivel nem tudunk azonosulni, mivel a specifikus talajérzékenységi tulajdonságoknak [VÁRALLYAY, 2002a, 2003] csupán egyikét képviseli, így térbeli érvényessége az összes folyamatra nem általánosítható).

A megyei szintủ feladat léptékéből adódóan következett, hogy a kulcsszerepet betöltő talajtani adatok alkalmazásának tekintetében két lehetőség adódott: a Digitális Kreybig Talajinformációs Rendszer (DKTIR) [azaz a Kreybig-féle átnézetes talajtérképezés eredményeinek térinformatikai feldolgozása és reambulációja révén elóálló térbeli talajtani információs rendszer (SZABÓ et al., 2000, 2005; PÁsZTOR et al., 2002, 2006)], illetve a Géczy-féle talajismereti- és talajhasznosítási térképek (térinformatikai feldolgozása alapján létrejövő térképi adatbázis) használata. A Géczy-féle térképi alapú talajtani információk térinformatikai feldolgozása több mühelyben is megkezdődött (VE Georgikon Kar, DE ATC, SzIE KTI, MTA TAKI), de éppen emiatt ennek egyelőre nincs egységes módszertana és a végtermékként kialakuló regionális adatbázisok harmonizálása sem történt meg. A kidolgozandó megyei szintủ rendezési tervek viszont olyan egységes módszertan és digitális adatrendszer rendelkezésre állását tételezik fel, amely egyelőre csak a DKTIR esetén biztosítható. Másrészről figyelemmel kellett lenni arra is, hogy a különféle méretarányú és tematikájú talajtani adatbázisok (az AGROTOPO, illetve a DKTIR és a Géczi Rendszer) nem használhatók direkt módon egymás alternatíváiként a léptékváltás miatt, elsősorban a talajok jellemzésének eltérő metodikája miatt. A DKTIR alapján ez a „,downscaling” feladat egyszerübben kivitelezhetőnek tünik, mivel az AGROTOPO alapját képező agrotopográfiai térképek szerkesztésénél megkülönböztetett jelentőséggel bírt a Kreybig-féle átnézetes talajismereti térképsorozat (VÁRALLYAY et al., 1979, 1980). Annak a ténynek köszönhetően, hogy döntően a Kreybig térképek felhasználásával, azok elemzésével és generalizálásával születtek, a DKTIR egyértelmübben válthatja az AGROTOPO-t, az annak használatára már nem releváns kistáji/kistérségi szinten. 


\section{Eredmények és értékelés ük}

Agráralkalmassági értékelés

Az agráralkalmassági kategóriák meghatározásához országos szinten az AGROTOPO adatbázisból használt paraméterek a következők voltak: a talaj fizikai félesége, a talaj kémhatása és mészállapota, a talaj vízgazdálkodási tulajdonságai. A talajok vízgazdálkodási kategória-rendszere nagyrészt, de nem teljesen a talajok fizikai féleségétől, többek között a mechanikai összetételtől és a talaj szerkezetétől függ. Másrészt az AGROTOPO alapjául szolgáló Kreybig térképek (csakúgy, mint

\section{1. táblázat}

A DKTIR adatbázisból az agráralkalmasság számításához használható talajtani paraméterek, illetve azok megfeleltetése az országosan használt AGROTOPO paramétereknek

\begin{tabular}{|c|c|c|}
\hline $\begin{array}{c}\text { Kiindulási talajtani } \\
\text { paraméterek }\end{array}$ & $\begin{array}{c}\text { (2) } \\
\text { Megfeleltethető talajtani } \\
\text { paraméterek } \\
\text { DKTIR/megyei szint }\end{array}$ & $\begin{array}{c}\text { A megyei szintü } \\
\text { agráralkalmassági számítás- } \\
\text { nál használt talajtani } \\
\text { paraméterek }\end{array}$ \\
\hline $\begin{array}{c}\text { 1. talaj fizikai félesége } \\
\text { 2. vízgazdálkodási } \\
\text { tulajdonságok }\end{array}$ & $\begin{array}{c}\text { 1. összevont fizikai és } \\
\text { vízgazdálkodási kate- } \\
\text { góriák }\end{array}$ & $\begin{array}{c}\text { 1. Kreybig-féle tájtermeszté- } \\
\text { si kategóriák }\end{array}$ \\
\hline 3. kémhatás és mészállapot & $\begin{array}{c}\text { 2. kémhatás és mészálla- } \\
\text { pot }\end{array}$ & \\
\hline & $\begin{array}{c}\text { 3. szervesanyag-készletre } \\
\text { vonatkozó kategóriák }\end{array}$ & $\begin{array}{c}\text { 2. szervesanyag-készlet } \\
\text { kategóriák }\end{array}$ \\
\hline
\end{tabular}

az ezek alapján építkező DKTIR) nem szolgáltatnak a kettőre vonatkozóan különkülön adatot. A fizikai és vízgazdálkodási kategóriák, illetve a kémhatás és mészállapot kategóriák összevonásával ezek eredőjeként az ún. tájtermesztési besorolást alkalmaztuk a talajok agráralkalmassági értékelésének egyik tényezőjeként. További paraméterként a talaj szervesanyag-készletet használtuk (1. táblázat).

A DKTIR reprezentatív talajszelvényre vonatkozó adatai (humusztartalom, humuszos réteg vastagsága) alapján származtattunk a foltokra vonatkozó szervesanyag-készlet értékeket. Mivel a követendő módszertan alapvetően kategóriaváltozókkal dolgozik, az egyes foltokra szervesanyag-készlet osztályokat határoztunk meg a rosszul ellátottól az igen jól ellátottig, 5 osztály definiálásával. A szervesanyag-ellátottsági kategóriákat a humuszréteg vastagság- és a humusztartalom kategóriák kereszttáblázatával adtuk meg (2A. és $2 \mathrm{~B}$. táblázat).

Az agráralkalmasság értékeléshez a tájtermesztési és a szervesanyag-ellátottsági kategóriákból kereszttáblázatot hoztunk létre. A kereszttáblázat elemeinek agráralkalmasság értékeit egy hármas agráralkalmassági skálán adtuk meg: 1 = gyenge, 2 = közepes, 3 = jó ( 3 . táblázat). A Pest megye területére elvégzett elemzés eredményeként adódott egyszerüsített agráralkalmassági térkép az 1. ábrán látható. 


\section{2. táblázat}

Szervesanyag-készlet homoktalajokon $\left(\mathrm{K}_{\mathrm{A}} \leq 30\right)(\mathrm{A})$, ill. homoknál nehezebb fizikai féleségü talajokon $\left(K_{A}>30\right)(B)$

A. Homoktalajokon $\left(K_{A} \leq 30\right)$

\begin{tabular}{|c|c|c|c|c|c|}
\hline \multirow{2}{*}{$\begin{array}{c}(1) \\
\text { Humusz } \\
\% \\
\end{array}$} & \multicolumn{5}{|c|}{ (2) Humuszos réteg vastagsága } \\
\hline & $\begin{array}{c}<20 \mathrm{~cm} \\
\text { sekély }\end{array}$ & $\begin{array}{c}20-40 \mathrm{~cm} \\
\text { közepes }\end{array}$ & $\begin{array}{c}40-60 \mathrm{~cm} \\
\text { mély }\end{array}$ & $\begin{array}{l}60-80 \mathrm{~cm} \\
\text { igen mély }\end{array}$ & $\begin{array}{l}80 \mathrm{~cm}< \\
\text { extrém }\end{array}$ \\
\hline $\begin{array}{l}<1 \% \\
\text { gyengén } \\
\text { humuszos }\end{array}$ & a) rossz & b) gyenge & b) gyenge & b) gyenge & b) gyenge \\
\hline $\begin{array}{l}1-2 \% \\
\text { közepesen } \\
\text { humuszos }\end{array}$ & b) gyenge & c) közepes & d) jó & e) igen jó & e) igen jó \\
\hline $\begin{array}{l}2-3 \% \\
\text { erősen } \\
\text { humuszos }\end{array}$ & c) közepes & d) jó & e) igen jó & e) igen jó & e) igen jó \\
\hline $\begin{array}{l}3 \%< \\
\text { igen erősen } \\
\text { humuszos }\end{array}$ & d) jó & e) igen jó & e) igen jó & e) igen jó & e) igen jó \\
\hline
\end{tabular}

B. Homoknál nehezebb fizikai féleségü talajokon $\left(K_{A}>30\right)$

\begin{tabular}{|l|l|l|l|l|l|}
\hline \multirow{2}{*}{$\begin{array}{c}\text { Humusz } \\
\%\end{array}$} & \multicolumn{5}{|c|}{$(3)$ Humuszos réteg vastagsága } \\
\cline { 2 - 6 } & $\begin{array}{l}\text { 0-20cm } \\
\text { vékony }\end{array}$ & $\begin{array}{l}20-40 \mathrm{~cm} \\
\text { sekély }\end{array}$ & $\begin{array}{l}40-60 \mathrm{~cm} \\
\text { közepes }\end{array}$ & $\begin{array}{l}60-80 \mathrm{~cm} \\
\text { mély }\end{array}$ & $\begin{array}{l}80 \mathrm{~cm}< \\
\text { igen mély }\end{array}$ \\
\hline $\begin{array}{l}<1 \% \\
\text { gyengén } \\
\text { humuszos }\end{array}$ & a) rossz & a) rossz & a) rossz & a) rossz & a) rossz \\
\hline $\begin{array}{l}1-2 \% \\
\text { gyengén } \\
\text { humuszos }\end{array}$ & a) rossz & b) gyenge & c) közepes & d) jó & d) jó \\
\hline $\begin{array}{l}2-3 \% \\
\text { közepesen } \\
\text { humuszos }\end{array}$ & b) gyenge & c) közepes & d) jó & d) jó & e) igen jó \\
\hline $\begin{array}{l}3-5 \% \\
\text { erósen } \\
\text { humuszos }\end{array}$ & c) közepes & d) jó & e) igen jó & e) igen jó & e) igen jó \\
\hline $\begin{array}{l}5 \%< \\
\text { átmenet a } \\
\text { szerves } \\
\text { talajok } \\
\text { felé }\end{array}$ & c) közepes & d) jó & e) igen jó & e) igen jó & e) igen jó \\
\hline
\end{tabular}


3. táblázat

Az agráralkalmasság kódolása

\begin{tabular}{|c|c|c|c|c|c|}
\hline \multirow[t]{2}{*}{ Kreybig-féle tájtermesztési kategóriák } & \multicolumn{5}{|c|}{$\begin{array}{l}\text { (2) Szervesanyag-ellátottsági } \\
\text { kategóriák* }\end{array}$} \\
\hline & $\mathrm{R}$ & Gy & $\mathrm{K}$ & $\mathrm{J}$ & $\mathrm{Ij}$ \\
\hline a) Savanyú, szerves anyagban szegény homok & 1 & 1 & 1 & 2 & 2 \\
\hline b) Savanyú, szerves anyagban gazdag homok & 1 & 1 & 1 & 2 & 2 \\
\hline c) Meszes, szerves anyagban szegény homok & 1 & 1 & 1 & 2 & 2 \\
\hline d) Meszes, szerves anyagban gazdag homok & 1 & 1 & 2 & 2 & 3 \\
\hline e) Kitűnő vályog és öntésiszap talaj & 2 & 2 & 3 & 3 & 3 \\
\hline f) Felszínben savanyú, kitünő vályog- és agyagtalajok & 1 & 2 & 2 & 3 & 3 \\
\hline $\begin{array}{l}\text { g) Igen erösen kötött, savanyú, mészigényes agyagok és vá- } \\
\text { lyogok }\end{array}$ & 1 & 1 & 1 & 2 & 3 \\
\hline h) Sekély termőrétegü talajok & 1 & 1 & 1 & 1 & 2 \\
\hline i) Tözeg és kotus talajok & 1 & 1 & 1 & 1 & 2 \\
\hline j) Mezőgazdasági termelésre alkalmas szikes talajok & 1 & 1 & 1 & 2 & 2 \\
\hline $\begin{array}{l}\text { k) Mezőgazdasági termelésre feltételesen alkalmas szikes } \\
\text { talajok }\end{array}$ & 1 & 1 & 1 & 1 & 1 \\
\hline 1) Mezőgazdasági termelésre alkalmatlan szikes talajok & 1 & 1 & 1 & 1 & 1 \\
\hline m) Időszakosan vízjárta területek & 1 & 1 & 1 & 2 & 2 \\
\hline n) Egyéb (erdők, tavak, nádasok, folyóvizek, települések) & - & - & - & - & - \\
\hline
\end{tabular}

Megjegyzés: R: rossz; Gy: gyenge; K: közepes; J: jó; Ij: igen jó

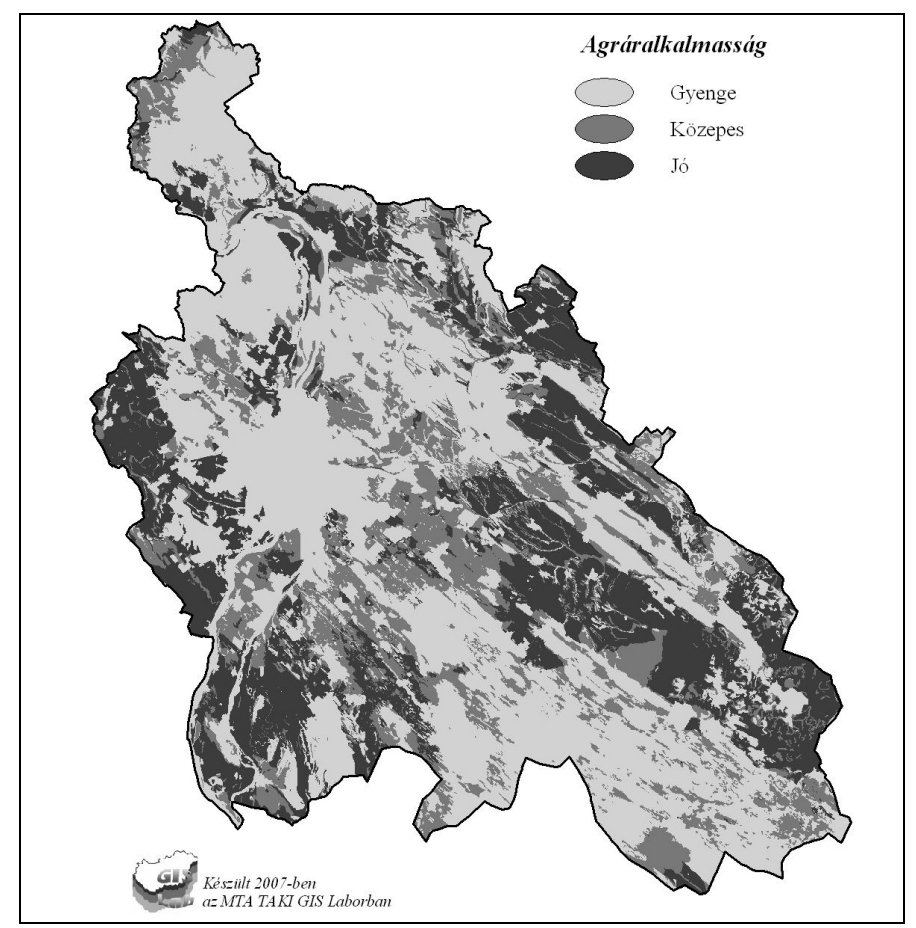

1. ábra Pest megye egyszerüsített agráralkalmassági térképe 


\section{Az erdötelepitési alkalmasság értékelése}

A PODMANICKY és munkatársai (2006) által alkalmazott módszertan az erdőtelepítési alkalmasságot két faktorra bontotta, úgymint a terület erdőgazdálkodásra való alkalmassága és az erdő környezetvédelmi funkciója iránti igénye. Meghatározásához országos szinten az AGROTOPO adatbázis alapján használt talajtani paraméterek a következők voltak: genetikai talajtípus, kémiai talajtulajdonságokra vonatkozó kategóriák, vízgazdálkodási tulajdonságok. A felsorolt paraméterek alapvetően a termőhelyi jellemzést szolgálják, annak eldöntésére, hogy egy terület alkalmas-e erdőtelepítésre, s ha igen, milyen gazdasági eredménnyel. Az AGROTOPOban szereplő genetikus talajtípust az erdészeti szakemberek az erdőtelepítésre való alkalmasság alapján interpretálták és eszerint 0 (kizárt) és 4 (kedvezö) közötti értékkel rangsorolták.

A Kreybig-féle térképek nem tüntettek fel genetikus talajtípust. A hozzájuk kapcsolódó ún. tájtermesztési térképek ellenben pont azzal a céllal készültek, hogy tájékoztassák a gazdálkodókat az adott terület mezőgazdasági szempontú termőhelyi adottságairól. Megfelelő szempontrendszer alapján az említett termőhelyi tulajdonságok „lefordíthatók” erdészeti szempontokat figyelembe vevő kategóriákra. A DKTIR ugyanis nem egyszerüen a Kreybig-féle Átnézetes Talajismereti Térképsorozat adatainak nyers digitális feldolgozása, hanem többek között integráltuk benne a tájtermesztési térképek információ-tartalmát is. Az egykori erdőterületekre (mivel kiestek a mezőgazdálkodás érdeklődési területéből) nem rendelkezünk ilyen méretarányban talajtani információkkal (bár az agrotopográfiai térképek és annak alapján az AGROTOPO ezen területekre is szolgáltat információt). Ennek oka, a hazai talajtérképezés egyik jellegzetessége, mely szerint a részletes felvételezések nem terjedtek ki az erdőterületekre. Az erdők alatti talajok jellemzése az erdészek által végzett termöhely leírás körében maradt. Napjainkban megindult ezen információk digitális feldolgozása, illetve a két terület közeledése, de a hatékony előrelépéshez elengedhetetlen a hagyományos mezőgazdasági alapú talajtérképezésnek az erdészeti célú termőhely-térképezéssel való harmonizációja és integrációja. Ez azonban az erdőtelepítésre potenciálisan alkalmas területek lehatárolását mégsem befolyásolja túlságosan, mivel a lehatárolás elsősorban a többnyire gyenge termőképességü,

\section{4. táblázat}

A DKTIR-ból az erdészeti alkalmasság számításához használható talajtani paraméterek, illetve azok megfeleltetése az országosan használt AGROTOPO paramétereknek

\begin{tabular}{|l|l|}
\hline \multicolumn{1}{|c|}{$\begin{array}{c}\text { Kiindulási talajtani paraméterek } \\
\text { AGROTOPO/országos szint }\end{array}$} & \multicolumn{1}{c|}{$\begin{array}{c}\text { Megfeleltethető talajtani paraméterek } \\
\text { DKTIR/megyei szint }\end{array}$} \\
\hline a) kategóriákba sorolt genetikus talajtípus & $\begin{array}{l}\text { d) korlátozott területi kiterjedéssel használ- } \\
\text { ható tájtermesztési kategóriák }\end{array}$ \\
\hline b) vízgazdálkodási tulajdonságok & $\begin{array}{l}\text { e) összevont fizikai és vízgazdálkodási } \\
\text { kategóriák }\end{array}$ \\
\hline c) kémhatás és mészállapot & $\begin{array}{l}\text { f) kémiai talajtulajdonságokra vonatkozó } \\
\text { kategóriák }\end{array}$ \\
\hline
\end{tabular}




\section{5. táblázat}

A releváns DKTIR paraméterek erdőgazdálkodásra való alkalmasság szempontú értékelése

\begin{tabular}{|c|c|}
\hline (1) Kategóriák & \\
\hline A. Tájtermesztési kategóriák & TajTerm \\
\hline a) Savanyú, szerves anyagban szegény homok & 0 \\
\hline b) Savanyú, szerves anyagban gazdag homok & 2 \\
\hline c) Meszes, szerves anyagban szegény homok & 0 \\
\hline d) Meszes, szerves anyagban gazdag homok & 1 \\
\hline e) Kitünő vályog és öntésiszap talaj & 1 \\
\hline f) Felszínben savanyú, kitünő vályog- és agyagtalajok & 2 \\
\hline g) Igen erősen kötött, savanyú, mészigényes agyagok és vályogok & 4 \\
\hline h) Sekély termőrétegü talajok & 0 \\
\hline i) Tőzeg és kotus talajok & 2 \\
\hline j) Mezőgazdasági termelésre alkalmas szikes talajok & 1 \\
\hline k) Mezőgazdasági termelésre feltételesen alkalmas szikes talajok & 0 \\
\hline 1) Mezőgazdasági termelésre alkalmatlan szikes talajok & 0 \\
\hline m) Időszakosan vízjárta területek & 3 \\
\hline n) Egyéb (erdők, tavak, nádasok, folyóvizek, települések) & - \\
\hline B. Összevont fizikai és vizgazdálkodási kategóriák & Fizik \\
\hline a) Jó víztartó és vízvezető képességü talajok & 2 \\
\hline b) Közepes vízvezető képességü, a vizet erősen tartó talajok & 2 \\
\hline c) Gyenge vízvezető képességü, a vizet erősen tartó, erősebben repedező talajok & 3 \\
\hline d) Nagy vízvezető képességü, még jó víztartó talajok & 1 \\
\hline e) Igen nagy vízvezető képességű, gyengén víztartó talajok & 0 \\
\hline f) Jó vízvezető képességü, a vizet igen erősen tartó talajok & 1 \\
\hline g) Köves felszín & 0 \\
\hline h) Kavicsos felszín & 0 \\
\hline i) Szikes talajok & 0 \\
\hline j) Tőzeges talajok & 2 \\
\hline k) Időszakosan vízállásos, vízjárta területek & 1 \\
\hline 1) Egyéb (erdők, tavak, nádasok, folyóvizek, települések) & - \\
\hline C. Kémiai talajtulajdonságokra vonatkozó kategóriák & Kemht \\
\hline a) Túlnyomóan semleges vagy gyengén lúgos, mésszel telített talajok & 1 \\
\hline $\begin{array}{l}\text { b) Túlnyomóan savanyú, mésszel telítetlen feltalajú, az altalajban már a fel- } \\
\text { színhez közel szénsavas meszet tartalmazó talajok }\end{array}$ & 2 \\
\hline $\begin{array}{l}\text { c) Túlnyomóan savanyúbb, telítetlen talajok, melyek altalaja a felszín közelé- } \\
\text { ben nem tartalmaz szénsavas meszet }\end{array}$ & 2 \\
\hline $\begin{array}{l}\text { d) Szántóföldi müvelésre alkalmas szikes talajok. Feltalajuk általában savanyú, } \\
\text { mésszel többnyire javíthatók. A termőréteg vastagsága } 50 \mathrm{~cm} \text { vagy több. }\end{array}$ & 1 \\
\hline $\begin{array}{l}\text { e) Szántóföldi mủvelésre kevéssé vagy feltételesen alkalmas szikes talajok. } \\
\text { Mésszel feltételesen javíthatók. Termőréteg } 30-50 \mathrm{~cm} \text {. }\end{array}$ & 0 \\
\hline f) Szántóföldi müvelésre alkalmatlan szikes talajok, mésszel nem javíthatók & 0 \\
\hline g) Futóhomok & - \\
\hline h) Köves, sziklás területek & - \\
\hline i) Időszakosan vízállásos, vízjárta területek & 1 \\
\hline j) Egyéb (erdők, tavak, nádasok, folyóvizek, települések) & - \\
\hline
\end{tabular}

Erdőgazdálkodásra való alkalmasság: $0=$ kizárt; $4=$ kedvező 


\section{6. táblázat}

A releváns DKTIR paraméterek az erdő környezetvédelmi funkciója iránti igény szerinti értékelése

\begin{tabular}{|l|c|}
\hline \multicolumn{1}{|c|}{ Összevont fizikai és vízgazdálkodási kategóriák } & Fizik \\
\hline a) Jó víztartó és vízvezető képességủ talajok & 0 \\
b) Közepes vízvezető képességü, a vizet erösen tartó talajok & 0 \\
c) Gyenge vízvezető képességü, a vizet erösen tartó, erösebben repedező talajok & 0 \\
d) Nagy vízvezető képességü, még jó víztartó talajok & 0 \\
e) Igen nagy vízvezető képességü, gyengén víztartó talajok & 2 \\
f) Jó vízvezető képességü, a vizet igen erősen tartó talajok & 0 \\
g) Köves felszín & 1 \\
h) Kavicsos felszín & 1 \\
i) Szikes talajok & 2 \\
j) Tőzeges talajok & 1 \\
k) Időszakosan vízállásos, vízjárta területek & - \\
1) Egyéb (erdők, tavak, nádasok, folyóvizek, települések) & - \\
m) Tavak, nádasok, folyóvizek & - \\
n) Települések & \\
\hline
\end{tabular}

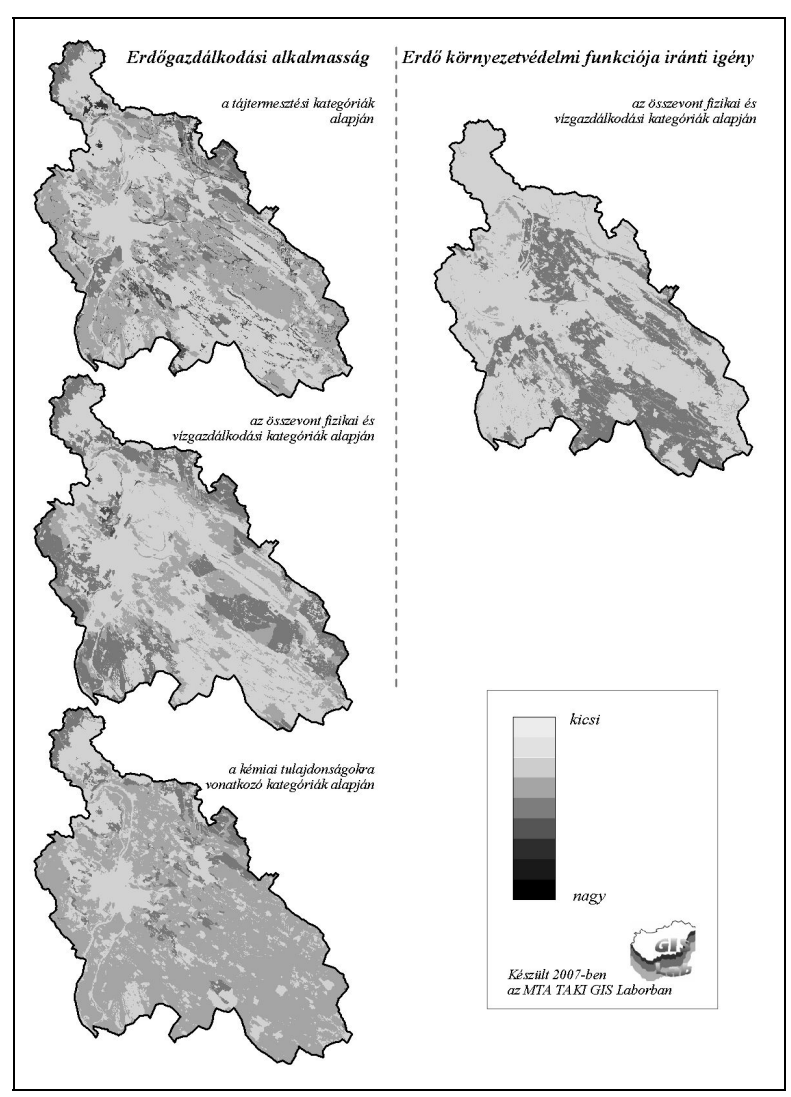

\section{2. ábra}

Az erdészeti alkalmasság egyszerüsített értékelésének talajtani vonatkozású tényező térképei Pest megyében 
jelenleg mezőgazdasági mủvelés alatt álló területeket érinti. Ezekre vonatkozóan, amennyiben a Kreybig térképezés idején is már mủvelés alatt álltak, rendelkezünk explicit talajtani adatokkal, ha pediglen akkori erdősültségük miatt most adathiánynyal szembesülünk, maga a földhasználati történelmi információ szolgálhatja a döntéshozás megkönnyítését. A megyei szintű feladatok elvégzéséhez a talajok vonatkozásában az országos léptékben használt AGROTOPO adatbázis releváns tematikáit a megyei szinten alkalmazandó releváns DKTIR tematikákra cseréltük (4. táblázat) úgy, hogy meghagytuk a vonatkozó tematikák országos léptékủ ponthatárait, illetve a nem talajos tematikákat (erdészeti klímazónák, lejtésviszonyok, vízvédelem ) és azok ponthatárait (5. táblázat).

Az erdőtelepítés környezeti meghatározottságának értékeléséhez országos szinten az AGROTOPO adatbázis alapján használt egyedüli talajtani paraméter a talaj fizikai félesége volt, melynek megyei szinten jól megfeleltethetők a DKTIR összevont fizikai és vízgazdálkodási kategóriái (6. táblázat). A Pest megye területére elvégzett elemzés eredményeként adódott erdészeti alkalmassági tényezőtérképek a 2. ábrán láthatók.

\section{A talaj környezeti érzékenységének értékelése}

PODMANICKY és munkatársai (2006) az országos szinten elvégzett elemzésük során a talaj környezeti érzékenységét csupán az erózió figyelembevételével fejezték ki, a talajveszteség lehetséges mértékének becslésével. Ezek alapján 2 t/ha/év mértékủ potenciális talajveszteség felett talajtani szempontból sérülékenynek tekintették a területet. A talajerózió azonban csak egy eleme az igen komplex talajdegradációs folyamatoknak, ezért megyei szinten nem tudtunk eltekinteni attól, hogy az erózióérzékenység mellett a fizikai és a kémiai degradáció szempontjából érzékeny, sérülékeny területekre is tekintettel legyünk, megpróbálva lehatárolni az általuk érintett területeket. Ehhez a DKTIR fizikai, kémiai, tájtermesztési, illetve szervesanyag-ellátottsági tematikáinak kategóriáit használtuk az alábbiak szerint.

A szélsőséges kémhatás-viszonyok alapján veszélyeztetettnek tekintettük azokat a területeket, amelyek talajaira a következők valamelyike teljesül:

- Túlnyomóan savanyúbb, telítetlen talajok, melyek altalaja a felszín közelében nem tartalmaz szénsavas meszet.

- Szántóföldi múvelésre kevéssé vagy feltételesen alkalmas szikes talajok. Mészszel feltételesen javíthatók. Termőréteg 30-50 cm.

- Szántóföldi müvelésre alkalmatlan szikes talajok, mésszel nem javíthatók.

A szélsőséges fizikai tulajdonságok alapján veszélyeztetettnek tekintettük azokat a területeket, amelyek talajaira a következők valamelyike teljesül:

- Gyenge vízvezető képességü, a vizet erősen tartó, erősebben repedező talajok.

- Igen nagy vízvezető képességü, gyengén víztartó talajok.

- Köves felszín.

- Időszakosan vízállásos, vízjárta területek.

- Szántóföldi művelésre kevéssé vagy feltételesen alkalmas szikes talajok. Mészszel feltételesen javíthatók. Termőréteg $30-50 \mathrm{~cm}$.

- Szántóföldi müvelésre alkalmatlan szikes talajok, mésszel nem javíthatók. 
- Futóhomok.

- Sekély termőrétegü talajok.

- Szervesanyag-ellátottsági kategóriája rossz besorolású.

A Pest megye területére elvégzett elemzés eredményeként adódott a talajok egyszerüsített környezeti érzékenység térképe, amely a 3. ábrán látható.

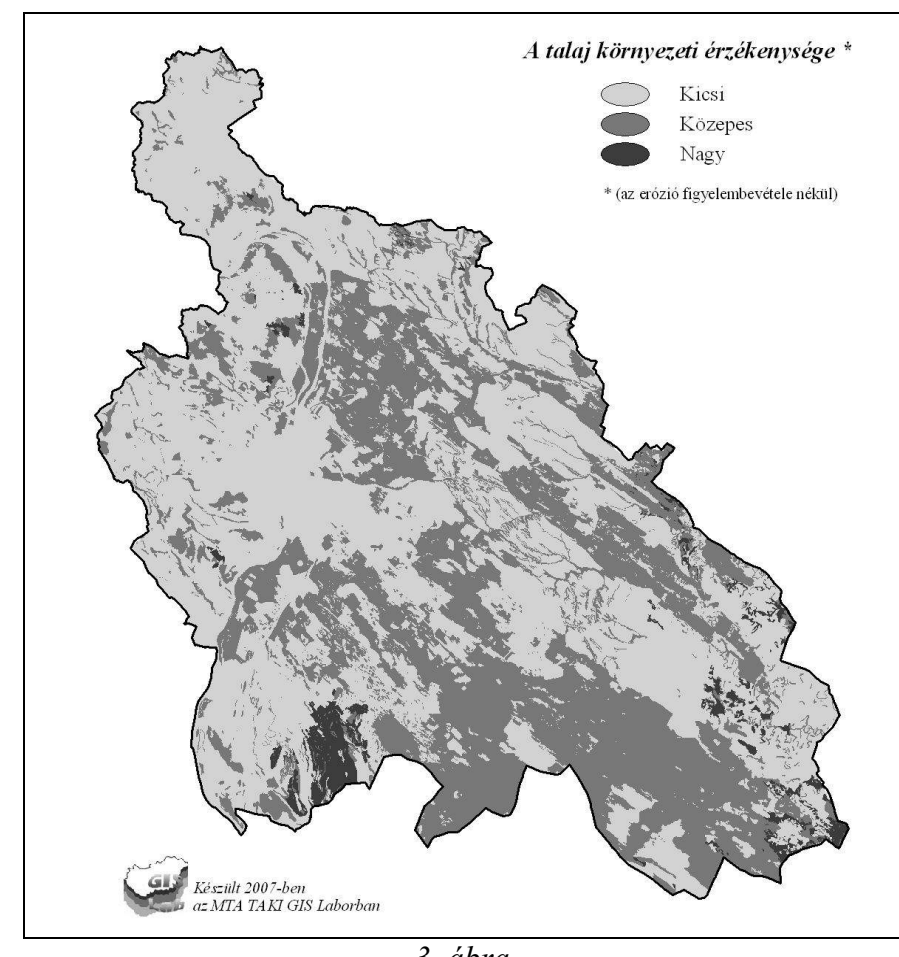

3. ábra

A talajok egyszerüsített környezeti érzékenysége Pest megyében

\section{Összefoglalás}

Országos léptékü, térképi alapú információk felhasználásával ökotípusos földhasználati lehatárolásra alkalmazható módszertanfejlesztés történt az Országos Területrendezési Terv számára. A részletesebb szintű rendezési tervek kidolgozásához egyrészt az országossal konzisztens módszertan alkalmazására, másrészt adekvát térbeli felbontású adatokra van szükség. Munkánkban Magyarország ökotípusos földhasználati vizsgálatának megyei szinten történő talajtani adatigényének kielégítésére vállalkoztunk.

A térbeli felbontás megkívánta részletességü térbeli talajtani információkat a Digitális Kreybig Talajinformációs Rendszer szolgáltatta. Az országos szinten elvégzett vizsgálatok fonalát követve, elvégeztük Pest megye talajainak (i) agráralkalmassági elemzését, (ii) az erdészeti alkalmasságra vonatkozó résztényezők 
interpretációját, illetve (iii) a talaj környezeti érzékenységének országos szinten alkalmazott értelmezésének kibővítésével a fizikai és a kémiai degradáció szempontjából érzékeny, sérülékeny területek lehatárolását.

Kulcsszavak: földhasználat értékelés, ökotípus, térbeli talajinformációs rendszer, területrendezési terv

Munkánkat a K60896 sz. OTKA pályázat támogatja.

\section{Irodalom}

ÁNGYÁN J. et al. (szerk.), 1999. Nemzeti Agrár-környezetvédelmi Program (a környezetkímélő, a természet védelmét és a táj megőrzését szolgáló mezőgazdasági termelési módszerek támogatására), Agrár-környezetgazdálkodási tanulmánykötetek, 1. kötet. FVM. Budapest.

BiRKÁS M. (szerk.), 2006. Földmüvelés és földhasználat. Mezőgazda Kiadó. Budapest.

BLUM, W. E. H., 1993. Soil protection concept of the Council of Europe and integrated soil research. In: Soil and Environment. Vol I. Integrated Soil and Sediment Research: A Basis for Proper Protection. (Eds.: EIJSACKERS, H. J. P. \& HAMERS, T.) 37-47. Kluwer Academic Publisher, Dordrecht.

CSETE L. \& LÁNG I., 2004. Agroökoszisztémák, regionalitás és biodiverzitás. AGRO-21 Füzetek. 37. 186-204.

DoBos, E. et al., 2002. The use of DEM and satellite data for regional scale soil databases. Agrokémia és Talajtan. 51. 263-272.

DÖMSÖDI J., 2006. Földhasználat. Dialóg Campus Kiadó. Budapest.

FODOR N. \& RAJKAI K., 2005. Számítógépes program a talajok fizikai és vízgazdálkodási jellemzőinek egyéb talajjellemzőkből történő számítására (TALAJTAnonc 1.0). Agrokémia és Talajtan. 54. 25-40.

GAÁL Z., MÁTÉ F. \& TÓTH G. (szerk.), 2003. Földminősítés és földhasználati információ. Veszprémi Egyetem. Keszthely.

HubreChTS, L. et al., 1998. From soil survey to quantitative land evaluation in Belgium. In: Research Report No. 4. 91-100. European Soil Bureau. Ispra, Italy.

LÁNG I., CSETE L. \& HARNOS Zs., 1983. A magyar mezögazdaság agroökológiai potenciálja az ezredfordulón. Mezőgazd. Kiadó. Budapest.

LÓCZY D., 2002. Tájértékelés, földértékelés. Dialóg Campus Kiadó. Budapest.

MAGDA S. et al., 2006. Agráralkalmassági és földhasználati vizsgálatok az ÉszakMagyarországi Régióban. In: Településrendezés, birtokrendezés. Előadások és poszterek összefoglalója. (Szerk.: DöMSÖDI J.) 45-47. Nyugat-Magyarországi Egyetem Geoinformatikai Kar. Székesfehérvár.

MAGYARI J., 2005. Térinformatikai módszerek alkalmazása az agrár-környezetgazdálkodás és vidékfejlesztés területén. Doktori értekezés. SzIE KTI. Gödöllö.

MCKenZIE, N. \& GAlLANT, J., 2007. Digital soil mapping with improved environmental predictors and models of pedogenesis. In: Digital Soil Mapping (Eds.: Lagacherie, P., McBratney, A. B. \& Voltz, M.). 327-349. Elsevier Science Publications. 
PÁSZTOR, L., SZABÓ, J. \& BAKACSI, Zs., 2002. GIS processing of large scale soil maps in Hungary. Agrokémia és Talajtan. 51. 273-282.

PÁszTOR L, SzABÓ J, BAKACsi Zs., 2006. Válasz Tóth Gergely és Máté Ferenc megjegyzéseire „Egy országos, átnézetes, térbeli talajinformációs rendszer kiépítésének igénye, lehetősége és lépései” cikkünk kapcsán. Agrokémia és Talajtan. 55. 479-486.

PODMANICZKY L. et al., 2006. Magyarország ökotípusos földhasználati vizsgálata. „Agráralkalmassági-környezetérzékenységi elemzés Magyarország területére”. Gödöllö.

SzABÓ J. \& PÁSZTOR L., 1994. Magyarország agroökológiai adatbázisa és annak környezetvédelmi felhasználási lehetőségei. In: Országos Környezetvédelmi Konferencia Kiadványa. Siófok. 156-163.

SzABÓ J., PÁSZTOR L. \& BAKACSI Zs., 2005. Egy országos, átnézetes, térbeli talajinformációs rendszer kiépítésének igénye, lehetősége és lépései. Agrokémia és Talajtan. 54. 41-58.

SzABÓ J. et al., 2000. Kreybig Digitális Talajinformatikai Rendszer (Elözmények, térinformatikai megalapozás). Agrokémia és Talajtan. 49. 265-276.

TAMÁS J., 2006. Az agrár- és környezetvédelmi célú földhasználati konfliktusok kezelése térbeli optimalizációs eljárásokkal. In: Településrendezés, birtokrendezés. Előadások és poszterek összefoglalója. (Szerk.: DöMSÖDI J.) 31-32. NyugatMagyarországi Egyetem Geoinformatikai Kar. Székesfehérvár.

VÁRALlYAY GY. (szerk.), 1995. TIM: Talajvédelmi Információs és Monitoring Rendszer. 1. kötet. Módszertan. FM Növényvédelmi és Agrár-környezetgazdálkodási Főosztály. Budapest.

VÁRAllyay GY., 1997. A talaj funkciói. Magyar Tudomány. 42. (12) 1414-1430.

VÁRAllyay Gy., 2001. A talaj vízgazdálkodása és a környezet. Magyar Tudomány. 46. (7) 799-815.

VÁRALlyAy GY., 2002a. A talajok környezeti érzékenységének értékelése. Agrártudományi Közlemények. Debreceni Egyetem. 9. 62-74.

VÁRALLYAY GY., 2002b. A talaj multifunkcionalitásának szerepe a jövő fenntartható mezőgazdaságában. In: A növénytermesztés szerepe a jövő multifunkcionális mezőgazdazságában. Ötven éves az Acta Agronomica Hungarica. Jubileumi tudományos ülés, 2002. XI. 19. Martonvásár. 13-25.

VÁRALlyAY GY., 2003. A talaj környezeti érzékenységének értékelése. Tájökológiai Lapok. 1. (1) 45-62.

VÁRALlyAY GY. \& LÁNG I., 2000. A talaj kettős funkciója: természeti erőforrás és termőhely. Debreceni Egyetem Agrártudományi Közlemények. 5-19.

VÁRALLYAY GY. et al., 1979. Magyarország termőhelyi adottságait meghatározó talajtani tényezők 1:100.000 méretarányú térképe I. Agrokémia és Talajtan 28. 363 384.

VÁRALLYAY GY. et al., 1980. Magyarország termőhelyi adottságait meghatározó talajtani tényezők 1:100.000 méretarányú térképe II. Agrokémia és Talajtan 29. 35-76.

Wösten, J. H. M. et al., 1998. Using existing soil data to derive hydraulic parameters for simulation models in environmental studies and in land use planning. DLO Winand Staring Centre. Report 157. Wageningen, The Netherlands.

Érkezett: 2007. február 12. 


\title{
Application of the Kreybig Digital Soil Information System to solve land use problems at regional level
}

\author{
J. SZABÓ, L. PÁSZTOR, Z. BAKACSI, P. LÁSZLÓ and A. LABORCZI
}

Research Institute for Soil Science and Agricultural Chemistry of the Hungarian Academy of Sciences, Budapest

\section{Summary}

Using map-based information on a national scale, a methodology was elaborated for the deliniation of land use categories based on ecotypes for use in the National Regional Development Plan. The elaboration of more detailed plans requires the application of methodologies consistent with the national scale and the use of data with suitable spatial resolution. The present work was aimed at satisfying the soil data requirements at county level for application in the national land use study.

The desired spatial resolution of soil information was achieved using the Kreybig Digital Soil Information System (KDSIS = DKTIR). Following the pattern of the nationwide analysis, an analysis was made of the suitability of soils in Pest County for use in agriculture, an interpretation was given of factors determining the suitability of land for forestry, and the approach used at the national level was extended to provide a deliniation of vulnerable zones with soils sensitive to physical and chemical degradation.

Table 1. Soil parameters from the DKTIR database, applicable for the calculation of agricultural suitability, and how they compare with the AGROTOPO parameters used on a national scale. (1) Initial soil parameters. AGROTOPO/national level: 1. soil texture; 2. soil water management categories; 3 . soil reaction and carbonate status. (2) Equivalent soil parameters. DKTIR/county level: 1. combined soil texture and water management categories; 2 . soil reaction and carbonate status; 3 . organic matter resource categories. (3) Soil parameters used to calculate agricultural suitability at county level: 1. Kreybig's soilscape categories; 2 . organic matter resource categories.

Table 2. Organic matter contents of sandy soils $\left(\mathrm{K}_{\mathrm{A}} \leq 30\right)(\mathrm{A})$, and of soils with a texture heavier than sand $\left(\mathrm{K}_{\mathrm{A}}>30\right)(\mathrm{B})$. A. (1) Humus \% (from top to bottom): poor, moderate, good, very good humus content. (2) Thickness of the humus layer (from left to right): shallow; moderate; deep; very deep; extremely deep. B. (1) Humus \% (from top to bottom): poor, moderate, very good humus content; transition towards organic soils. (3) Thickness of the humus layer (from left to right): thin; shallow; moderate; deep; very deep. a) very poor; b) poor; c) medium; d) good; e) very good.

Table 3. Codes used for agricultural suitability. (1) Kreybig's soilscape categories. a) Acidic, humus-poor sand; b) acidic, humus-rich sand; c) calcareous, humus-poor sand; d) calcareous, humus-rich sand; e) excellent loam and alluvial silt soil; f) excellent loam and clay soil, acidic in the surface layers; g) very heavy, acidic, lime demanding clays and loams; h) soils with a shallow humus layer; i) organic soils; j) salt affected soils suitable for agricultural production; k) salt affected soils conditionally suitable for agricultural production; 1) salt affected soils unsuitable for agricultural production; m) periodically waterlogged soils; n) other (forests, lakes, reedbeds, rivers and streams, 
built-up areas). (2) Organic matter supply categories: R: very poor; Gy: poor; K: medium; J: good; Ij: very good.

Table 4. Soil parameters from the DKTIR database, applicable for the calculation of forestry suitability, and how they compare with the AGROTOPO parameters used on a national scale. (1) Initial soil parameters. AGROTOPO/national level: a) genetic soil type categories; b) soil water management categories; c) soil reaction and carbonate status. (2) Equivalent soil parameters. DKTIR/county level: d) soilscape categories applicable over a limited area; e) combined soil texture and water management categories; f) categories related to chemical soil properties.

Table 5. Evaluation of relevant DKTIR parameters in terms of suitability for forestry. (1) Categories. A. For soilscape categories, see Table 3. B. Combined texture and water management categories. a) soils with good water retention and hydraulic conductivity; b) soils with moderate water conductivity and high water retention; c) soils with poor hydraulic conductivity and very high water retention, prone to cracking; d) soils with good hydraulic conductivity and water retention; e) soils with very good hydraulic conductivity but poor water retention; f) soils with good hydraulic conductivity and very high water retention; g) stony surface; h) gravelly surface; i) salt affected soils; j) peat soils; k) areas periodically waterlogged; 1) other (forests, lakes, reedbeds, rivers and streams, built-up areas). C. Categories related to chemical soil properties. a) mainly neutral or mildly alkaline, calcareous soils; b) soils mainly acidic and non-calcareous from the surface, but containing lime featured by effervescence with dilute acid in the subsoil near to the surface; c) mainly more acidic, non-calcareous soils, where the subsoil immediately below the topsoil contains no lime featured by effervescence with dilute acid; d) salt affected soils suitable for arable use, with $50 \mathrm{~cm}$ or more topsoil, which is generally acidic, but can be ameliorated with lime; e) salt affected soils less suitable for arable use, which can possibly be ameliorated with lime, having a $30-50 \mathrm{~cm}$ thick topsoil; f) salt affected soils unsuitable for arable use, which cannot be ameliorated with lime; g) shifting sand; h) stony or rocky areas; i) areas periodically waterlogged; j) other (forests, lakes, reedbeds, rivers and streams, built-up areas).

Table 6. Evaluation of relevant DKTIR parameters in terms of the environment protection function of forests. (1) Combined soil texture and water management categories: see Table 5.

Fig. 1. Simplified agricultural suitability map for Pest County. Legend (from top to bottom): poor, moderate, good.

Fig. 2. Maps for the simplified evaluation of the suitability of land for forestry and the environment protection function of forests in Pest County. Left side, from top to bottom: on the basis of soilscape categories; on the basis of combined soil texture and water management categories; on the basis of categories related to soil chemical properties. Right side: on the basis of soil texture and water management categories. Legend (from top to bottom): poor ... good.

Fig. 3. Simplified environmental sensitivity of the soils in Pest County. Legend (from top to bottom): slight; medium; great. 